Acta vet. scand. 1986, 27, 33-48.

From Centre de Recherche en Reproduction Animale, Faculté de Médecine Vétérinaire, Université de Montréal, C. P. 5000, SaintHyacinthe, Québec, Canada and the Department of Animal Reproduction, Royal Veterinary and Agricultural University, Copenhagen, Denmark.

\title{
BISECTION OF POST-COMPACTION BOVINE EMBRYOS: THE DIFFERENCE IN VIABILITY BETWEEN THE TWO MONOZYGOTIC HALVES
}

By

\author{
L. Picard, T. Greve, W. A. King, K. J. Betteridge \\ and P. Holm Jorgensen
}

PICARD, L., T. GREVE, W. A. KING, K. J. BETTERIDGE and P. HOLM JØRGENSEN: Bisection of post-compaction bovine embryos: The difference in viability between the two monozygotic halves. Acta vet. scand. 1986, 27, 33-48. - Bisection of bovine post-compaction embryos has become a useful tool for improving embryo transfer results. Compared to pre-compaction division, the technique is simpler but is does involve some cellular damage and rarely provides two completely identical "halves". Monozygotic pairs can therefore be divided into "good" and "poor" half embryos. By 4-6 h of culture in vitro, "good" halves remained significantly more viable than their poorer counterparts. Cytological evaluation after $24 \mathrm{~h}$ culture shows that the morphologically better halves contain more cells (an average of 45.9 vs 23.0) and have a higher mitotic index $(6.1 \%$ vs $3.1 \%)$ than the poorer halves. The single transfer of 26 half-embryos resulted in 15 pregnancies $(55.6 \%)$ but no difference could be demonstrated between the results obtained with halves of different sizes. Nevertheless, the in vitro results support the contention that bigger halves give better results and also demonstrate that one half-embryo cannot be used as a control for the other in viability studies.

demi embryos; embryotransfer; survival; microsurgery; success r ate.

Development modifications of the early mammalian embryo must be considered when embryo bisection or splitting is performed. Compaction marks the first visible event in cellular differentiation of the mammalian embryo; in cattle it occurs at some time between days 5 and 6 (oestrus $=$ day 0 ). During compaction the peripheral cells of the morula undergo a series of modifications and form the trophectoderm, thus losing their totipotency (Tarkowski \& Wroblewska 1967, Gardner 1972, Du- 
cibella et al. 1975, Johnson \& Ziomek 1982, Pratt et al. 1982, Ziomek et al. 1982). Concomitantly, the interior cells remain loosely attached, spherical in shape and form the inner cell mass (Tarkowski \& Wroblewska 1967, Ducibella et al. 1975). These inner cell mass cells are believed to remain pluripotent because, after being isolated immunosurgically, they can reform vesicular structures and differentiate into three germinal layers (Hogan \& Tilly 1978, Wiley et al. 1978).

Before compaction, blastomeres can be easily separated with minimal damage, but their survival rate after direct transfer to recipients when the zona pellucida has been opened or removed is low (Modlinski 1970, Trounson \& Moore 1974, Massey et al. 1982). This poor survival has been attributed to several factors including disaggregation due to the low adherence between the cells (Bronson \& McLaren 1970, Willadsen \& Fehilly 1983) and detrimental effects of the direct contact of the cells with the endometrium (Modlinski 1970). Survival rates can be improved by embedding the groups of blastomeres in agar to maintain them in close contact, then transferring them temporarily to the oviduct of an intermediate recipient allowing compaction to occur, and finally transferring the post-compaction embryos to definitive recipients (Willadsen 1979). Investigation of the developmental potential of blastomeres from precompaction bovine embryos with such techniques showed the viability of manipulated embryos containing half the normal number of cells to be similar to that of whole embryos after transfer. However, onequarter embryos had a reduced viability and, in sheep, oneeighth embryos usually only formed trophoblastic vesicles, apparently because of a lack of inner cells at the morula stage. Nevertheless, the transfer of ovine and bovine quarter embryos has resulted in the birth of quadruplets and triplets, respectively (Willadsen \& Polge 1981, Willadsen et al. 1981, Willadsen 1982, Willadsen \& Fehilly 1983).

When division of embryos is delayed until post-compaction stages, some damage to the cells is inevitable but the adverse effects of this are apparently limited. This is evidenced by the relatively high pregnancy rates abtained after transfer of embryos bisected at these stages, although they are slightly lower than those obtained with whole embryos. Further, re-formation of the blastocoele and restoration of normal embryonic morphology is extremely rapid after bisection (Ozil 1983, Wiliams et al. 
1983, 1984, Picard et al. 1985). Division of post-compaction embryos into four is likely to damage even more cells but, even so, the transfer of day-6 quarter embryos has produced twins (Voekel et al. 1984).

No prospective studies have been made to compare the viability of embryos split at pre- or post-compaction stages, but because of its simplicity, post-compaction bisection has been widely adopted by commercial embryo transfer units (Baker \& Shea 1985). Using post-compaction embryos, the high number of cells and their close adherence make it unlikely that splitting will produce two really identical "halves": in fact they can be separated into "good" and "poor" halves according to size, or, when both are of the same size, according to morphology (Picard et al. 1984, 1985). This study was conducted to evaluate the in vitro and in vivo viability of individual half-embryos according to their proportion of the initial post-compaction embryo.

\section{MATERIALS AND METHODS}

Day-6 or day-7 embryos were collected non-surgically from superovulated Holstein cows (Greve 1981) and transferred to a culture medium consisting of Dulbecco's phosphate-buffered saline (PBS) supplemented with $20 \%$ fetal calf serum plus 100 IU penicillin and $100 \mu \mathrm{g}$ streptomycin per ml. They were classified from A to D; A being excellent, B good, C poor and D degenerated (Elsden et al. 1978). Class A and B embryos were selected for bisection and class D (and sometimes C) embryos were used to provide surrogate zonae pellucidae.

Bisection was accomplished with two Leitz micromanipulators under a compound microscope at a magnification of $100 \times$ as described previously (Picard et al. 1985). Briefly, the instruments used are essentially those described by Williams \& Seidel (1983) except for the knife which was made with a triangular

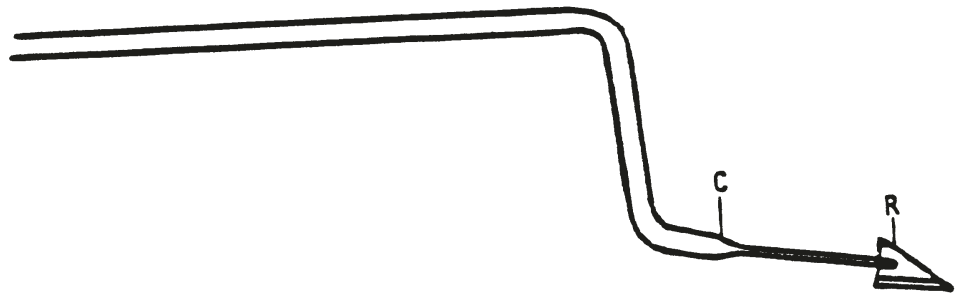

F i g u re 1. Illustration of the knife used to bisect bovine embryos. $\mathrm{R}$ : Piece of razor blade; C: Drawn capillary tube. 
piece of razor blade glued to a glass capillary tube so that its cutting was facing downward (Fig. 1). The embryos to be split were individually placed each with a degenerate embryo (or ovum) in separate drops $(\simeq 0.5 \mathrm{ml})$ of culture medium lined up in a $100 \mathrm{~mm}$ plastic Petri dish. The drops were then covered with paraffin oil to prevent evaporation and to protect them from contamination. The degenerate embryo or ovum was first grasped with the suction pipette and held on the bottom of the dish while its zona pellucida was opened over about one-half of its circumference by a descending movement of the blade. After releasing the opened degenerate embryo, the viable embryo was similarly grasped and cut, except that it was held so that the cellular mass was also partly cut into two equal portions by the blade. If the embryo was at the blastocyst stage, the inner cell mass was split during this step. Once the blade was on the bottom of the dish, it was left in position to retain the cellular mass while the zona pellucida was withdrawn with the holding pipette. Retraction of the blade, followed by another up, down and retraction movement, completed the splitting. When all the embryos in the dish were split, the blade was exchanged for a suction pipette. This was used to empty the opened degenerate embryos of their contents and to place each half-embryo into one of the two zonae pellucidae in each drop.

Immediately after micromanipulation, with an exception described below, one half of each pair was designated as the "good" half and the other as the "poor", according to either their size or their morphology. The proportion of the initial embryo that each half-embryo represented was also estimated; the pairs were recorded as being $1 / 4$ and $3 / 4,1 / 3$ and $2 / 3$ or $1 / 2$ and $1 / 2$ of the whole embryo.

The viabilities of the half-embryos were tested by in vitro and in vivo experiments. In the in vitro experiment, both halves from 27, 41 and 43 embryos were cultured for $2 \mathrm{~h}, 4$ to $6 \mathrm{~h}$ and 18 to $24 \mathrm{~h}$ respectively in culture medium at $37^{\circ} \mathrm{C}$. Thirty-seven whole embryos were cultured for $24 \mathrm{~h}$ in the same conditions to serve as controls. In the 18 to $24 \mathrm{~h}$ culture group, the halves were cultured in pairs and so the initial morphological classification could not be linked with the post-culture evaluation when they were of the same initial size $(1 / 2-1 / 2)$. Consequently, these were only separated into "good" and "poor" halves morphologically at the end of the culture period. In the other two groups, "good" 
and "poor" halves were cultured separately. At the end of the culture period, all embryos were reclassified A to D using the same criteria as for whole embryos before splitting. For the purposes of this study, class A and B embryos were considered viable and class $\mathrm{C}$ and $\mathrm{D}$ embryos as non-viable. "Viability" results for the in vitro experiment therefore express the percentage of class $A$ and $B$ embryos present at a given time. At the end of the $24 \mathrm{~h}$ culture period, both halves of 35 pairs and the 37 controls were fixed for cytological analysis following the method described by King (1984).

In the in vivo experiment, the halves of 18 embryos were transferred non-surgically to 31 synchronised recipients using $0.25 \mathrm{ml}$ French straws in a Cassau insemination gun (IMV, L'Aigle, France) as described by Greve (1981). Twenty-six halves were transferred individually but 10 halves had to be transferred as monozygotic pairs due to lack of recipients. Transfers, including both members of monozygotic pairs, were made to the uterine horn ipsilateral to the palpated corpus luteum.

Chi square and Student $t$ tests for pairwise comparisons where appropriate were used for statistical analysis.

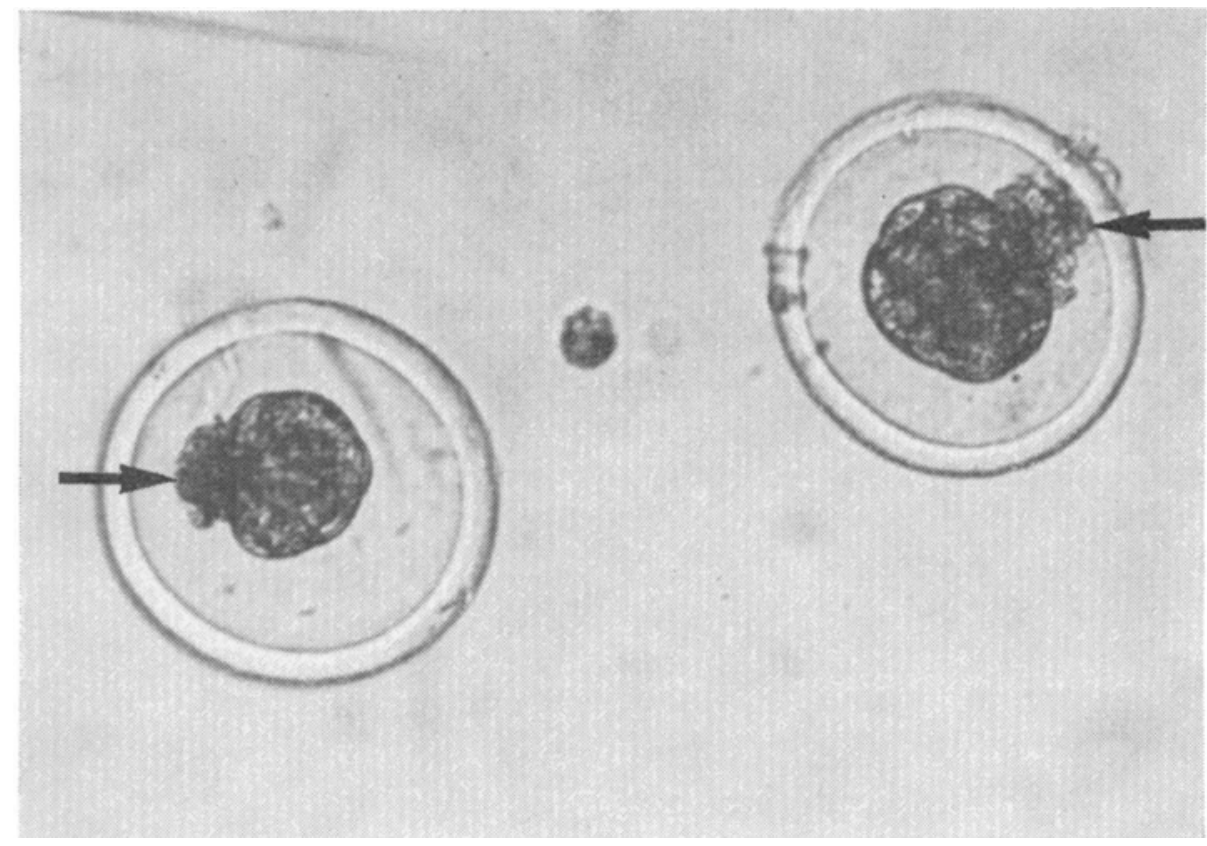

F i g u r e 2. Bisected embryo 2 h after division. "Good" and "poor" halves are on the right and left side respectively. The arrows are pointing to the cellular debris (pyknotic cells) on the cut surface. 


\section{RESULTS}

After splitting, it was possible to see pyknotic cells on the cut surface of some half-embryos (Fig. 2).

The viabilities of "halves" at various times in relation to the actual portion of the whole embryo that they represented are depicted in Figs. 3, 4 and 5. After $2 \mathrm{~h}$ in culture, there was no statistical difference in the viability of the "halves" of various sizes, but after $4-6 \mathrm{~h}$ and $18-24 \mathrm{~h}$ the differences were highly significant $(P<0.01)$. The difference in the viability of all the "poor" (whether $1 / 4,1 / 3$ or $1 / 2)$ compared to the "good" $(1 / 2,2 / 3$, $3 / 4$ ) halves was also highly significant for these two culture times $(19 \%$ vs $74 \%, 18-24 \mathrm{~h}$, and $56 \%$ vs $93 \%, 4-6 \mathrm{~h} ; \mathrm{P}<0.01)$.

The fixation of 35 "good" and "poor" paired halves after 24 $h$ of culture, resulted in preparations from all 35 "good" halves

\section{EFFECT OF SIZE ON VIABILITY - AT $2 \mathrm{H}$}

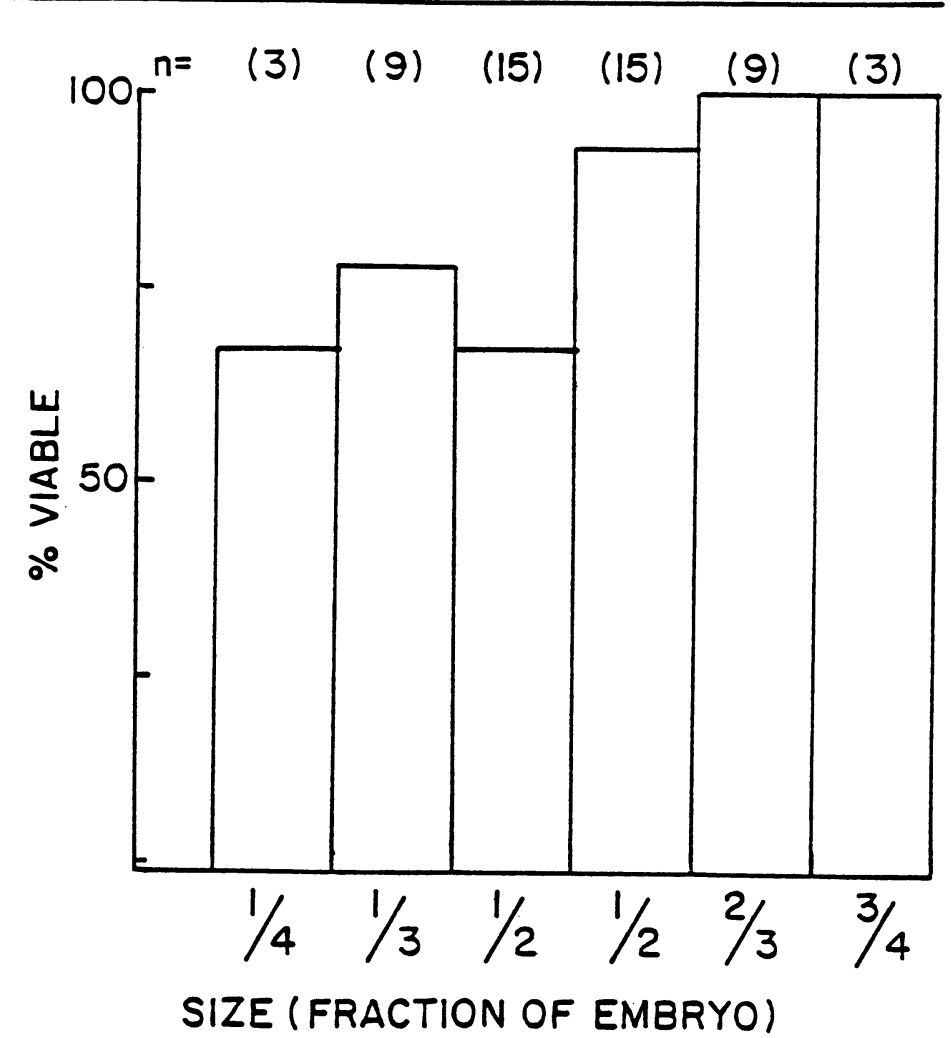

Figure 3. Effect of size of half-embryos on the viability following a $2 \mathrm{~h}$ culture period. 
EFFECT OF SIZE ON VIABILITY -AT4-6H

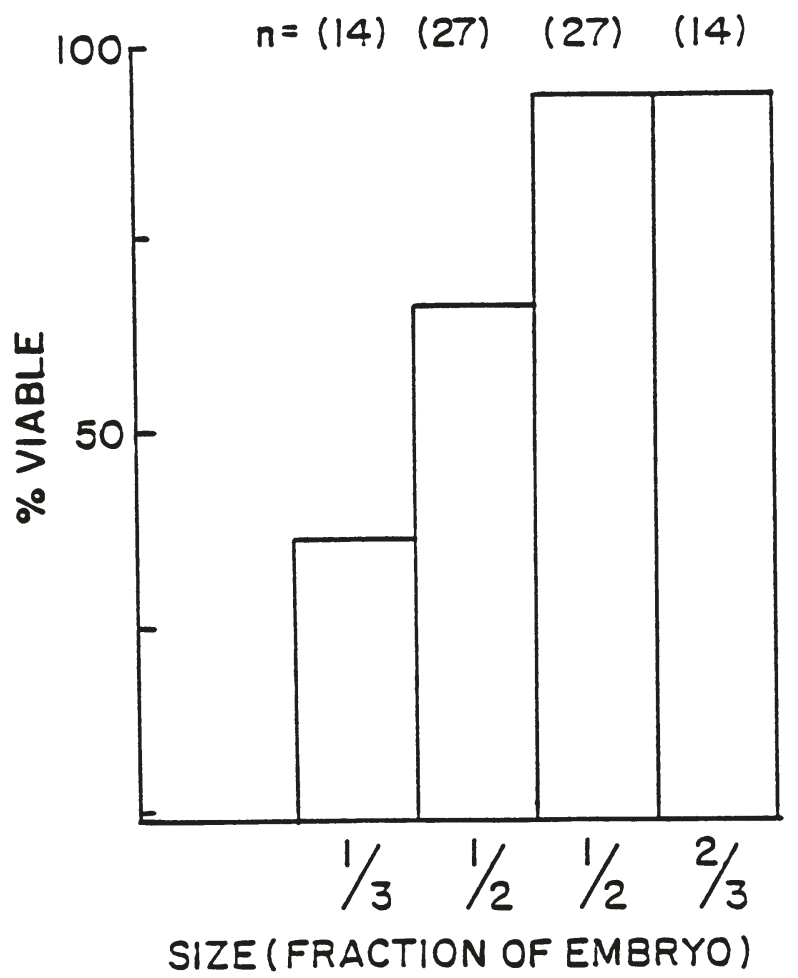

Figure 4. Effect of size of half-embryos on the viability following a $4-6 \mathrm{~h}$ culture period.

but from only 29 "poor" halves, no nuclei being found in the 6 other slides prepared from degenerate "poor" halves. Thus only 29 preparations from these halves were included in the analysis of results as it was not known if the absence of cells was real or caused by a technical error. Data from the cytological study of the "poor" and "good" halves are presented in Table 1. Both the mean cell content and the mitotic index of the "good" halves $(45.9,6.1 \%)$ were significantly higher than those of the "poor" halves $(23.0,3.1 \%)$. There was a significantly higher proportion of cells with pyknotic nuclei in the "poor" $(57 \%)$ than in the "good" halves $(33 \%)$. It was possible to identify the sex chromosomes more frequently in the "good" (43\%) than in the "poor" halves $(7 \%)$. 


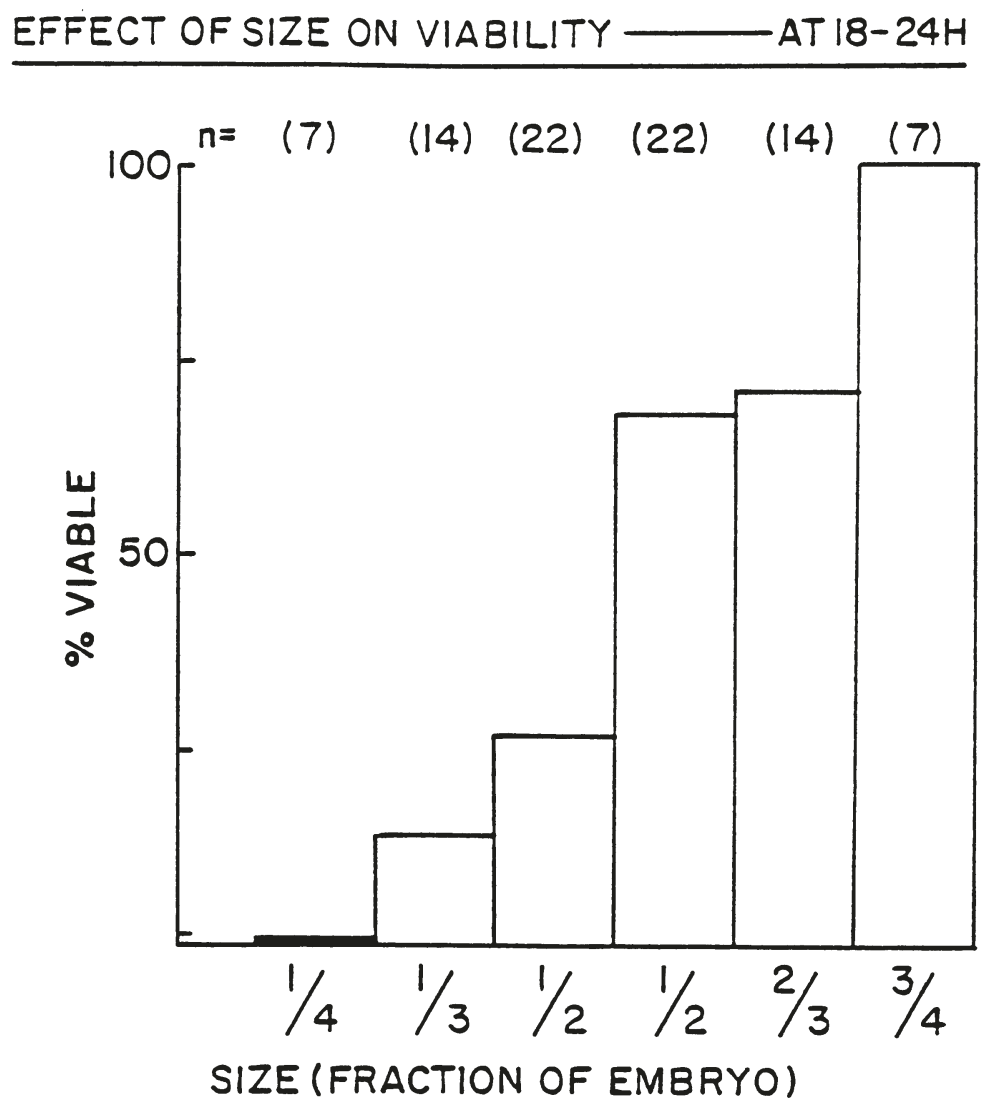

Figure 5. Effect of size of half-embryos on the viability following a $18-24 \mathrm{~h}$ culture period.

Table 1. Cytological comparison of pairs of half-embryos after $24 \mathrm{~h}$ culture.

\begin{tabular}{|c|c|c|c|c|c|c|c|}
\hline $\begin{array}{l}\text { Half- } \\
\text { embryos }\end{array}$ & $\begin{array}{c}\text { Total } \\
\text { no. }\end{array}$ & $\begin{array}{l}\text { No. with } \\
\text { metaphases }\end{array}$ & $\begin{array}{c}\text { Metaphases } \\
(\text { Mean 士 SEM) }\end{array}$ & $\begin{array}{c}\text { Cells } \\
(\text { Mean } \pm \text { SEM })\end{array}$ & $\begin{array}{c}\text { Mitotic } \\
\text { index } \\
(\text { Mean } \pm \text { SEM })\end{array}$ & $\begin{array}{l}\text { Pyknotic } \\
\text { nuclei }\end{array}$ & Sexed \\
\hline "Good" & 35 & $66 \%$ & $3.1 \pm 0.6$ & $45.9 \pm 3.4$ & $6.1 \pm 1.1$ & $33 \%$ & $43 \%$ \\
\hline "Poor" & 29 & $34 \%$ & $1.0 \pm 0.3$ & $23.0 \pm 1.1$ & $3.1 \pm 1.1$ & $57 \%$ & $7 \%$ \\
\hline \multicolumn{8}{|l|}{$\begin{array}{l}\text { Statistical } \\
\text { analysis: }\end{array}$} \\
\hline $\begin{array}{l}\text { Significance } \\
\text { Test used }\end{array}$ & & $\begin{array}{c}\mathrm{P}<0.05 \\
\mathrm{Chi}^{2}\end{array}$ & $\begin{array}{r}\mathrm{P}<0.01 \\
\text { Student } \mathrm{t}\end{array}$ & $\begin{array}{r}\mathrm{P}<0.01 \\
\text { Student } \mathrm{t}\end{array}$ & $\begin{array}{c}\mathrm{P}<0.01 \\
\text { Student } \mathrm{t}\end{array}$ & $\begin{array}{c}\mathrm{P}<0.01 \\
\mathrm{Chi}^{2}\end{array}$ & $\begin{array}{c}\mathrm{P}<0.01 \\
\mathrm{Chhi}^{2}\end{array}$ \\
\hline
\end{tabular}


Table 2. Cytological comparison of the sum of the half-embryo pairs with whole embryo controls after $24 \mathrm{~h}$ culture.

\begin{tabular}{lcccc}
\hline Embryo & $\begin{array}{c}\text { No. of } \\
\text { preparations }\end{array}$ & $\begin{array}{c}\text { Metaphases } \\
(\text { Mean } \pm \text { SEM) }\end{array}$ & $\begin{array}{c}\text { Cells } \\
\text { (Mean } \pm \text { SEM) }\end{array}$ & $\begin{array}{c}\text { Mitotic } \\
\text { index } \\
\text { (Mean } \pm \text { SEM) }\end{array}$ \\
\hline $\begin{array}{l}\text { "Good" }+ \\
\text { "poor" halves }\end{array}$ & 29 & $3.8 \pm 0.7$ & $67.8 \pm 4.8$ & $5.2 \pm 1.0$ \\
$\begin{array}{l}\text { Controls } \\
\begin{array}{l}\text { Statistical } \\
\text { analysis: }\end{array}\end{array}$ & 37 & $6.8 \pm 0.8$ & $81.5 \pm 5.0$ & $8.3 \pm 1.0$ \\
$\quad \begin{array}{l}\text { Significance } \\
\text { Test used }\end{array}$ & & $\mathrm{P}<0.01$ & non signif. & $\begin{array}{c}\mathrm{P}<0.05 \\
\text { Student } t\end{array}$ \\
\hline
\end{tabular}

Table 2 compares the sum of cytological data available from the 29 paired "good" and "poor" halves with those of the 37 control whole embryos. A significant difference was observed between the numbers of metaphases $(P<0.01)$ and the mitotic indices $(P<0.05)$ but not between mean cell numbers for the two groups. Cytological characteristics of the viable and nonviable halves are summarized in Table 3 . It can be seen that non-viable halves, irrespective of their classification as "good" or "poor", contained fewer cells than viable halves $(\mathrm{P}<0.05)$.

Table 3. Cytological characteristics of viable (class A or B) and non-viable (class C or D) "good" and “poor" halves after $24 \mathrm{~h}$ culture.

\begin{tabular}{lccc}
\hline $\begin{array}{l}\text { Half- } \\
\text { embryos }\end{array}$ & $\begin{array}{c}\text { No. of } \\
\text { preparations }\end{array}$ & $\begin{array}{c}\text { Cells } \\
\text { (Mean } \pm \text { SEM) }\end{array}$ & $\begin{array}{c}\text { Metaphases } \\
\text { (Mean } \pm \text { SEM) }\end{array}$ \\
\hline $\begin{array}{c}\text { Viable } \\
\text { "good" }\end{array}$ & 21 & $50.7 \pm 4.5 \dagger$ & $3.4 \pm 0.7$ \\
$\begin{array}{c}\text { "poor" } \\
\text { Non-viable }\end{array}$ & 6 & $32.3 \pm 4.9^{\star}$ & $2.3 \pm 0.9$ \\
"good" & & & \\
"poor" & 8 & $28.9 \pm 2.7 \dagger$ & $1.6 \pm 0.5$ \\
\hline
\end{tabular}

$\dagger^{\star}$ : Numbers marked with the same symbols are significantly different $\mathrm{P}<0.05$.

The results of the transfer of single and paired half-embryos are presented in Table 4. Fifteen 60-day pregnancies were obtained from 26 half-embryos transferred singly $(55.6 \%)$ for an efficiency (pregnancy per whole embryo) of $111.2 \%$. The pregnancies were obtained from both halves of 5 embryos (twinning 
rate of $38.5 \%)$ and one half of 5 others $(38.5 \%)$ while pregnancies were not obtained from either half of 3 embryos $(23.0 \%)$. After diagnosis of pregnancy at 60 days, 1 recipient aborted spontaneously (85 days), 4 pregnancies were terminated and the

T a b l e 4. Results obtained following non-surgical transfer of single or paired half-embryos to recipient heifers.

\begin{tabular}{|c|c|c|c|c|c|c|}
\hline & \multirow{2}{*}{$\begin{array}{l}\text { No. } \\
\text { embryos } \\
\text { split r }\end{array}$} & \multirow{2}{*}{$\begin{array}{l}\text { s No. } \\
\text { recipients }\end{array}$} & \multirow[b]{2}{*}{$\begin{array}{l}\text { No. } \\
\text { pregnant } \\
(\%)\end{array}$} & \multicolumn{3}{|c|}{ No. of embryos producing: } \\
\hline & & & & $\begin{array}{c}\text { twins } \\
(\%)\end{array}$ & $\begin{array}{c}\text { singletons } \\
(\%)\end{array}$ & $\begin{array}{c}\text { no } \\
\text { pregnancy } \\
(\%)\end{array}$ \\
\hline Single & 13 & 26 & $1557.7)$ & $5(38.5)$ & $5(38.5)$ & $3(23.0)$ \\
\hline Paired & 5 & 5 & $3(60)$ & $3(60)$ & $0(0)$ & $2(40)$ \\
\hline Total & 18 & 31 & $18(58.1)$ & $8(44.4)$ & $5(27.8)$ & $5(27.8)$ \\
\hline
\end{tabular}

\section{EFFECT OF SIZE ON PREGNANCYRATE}

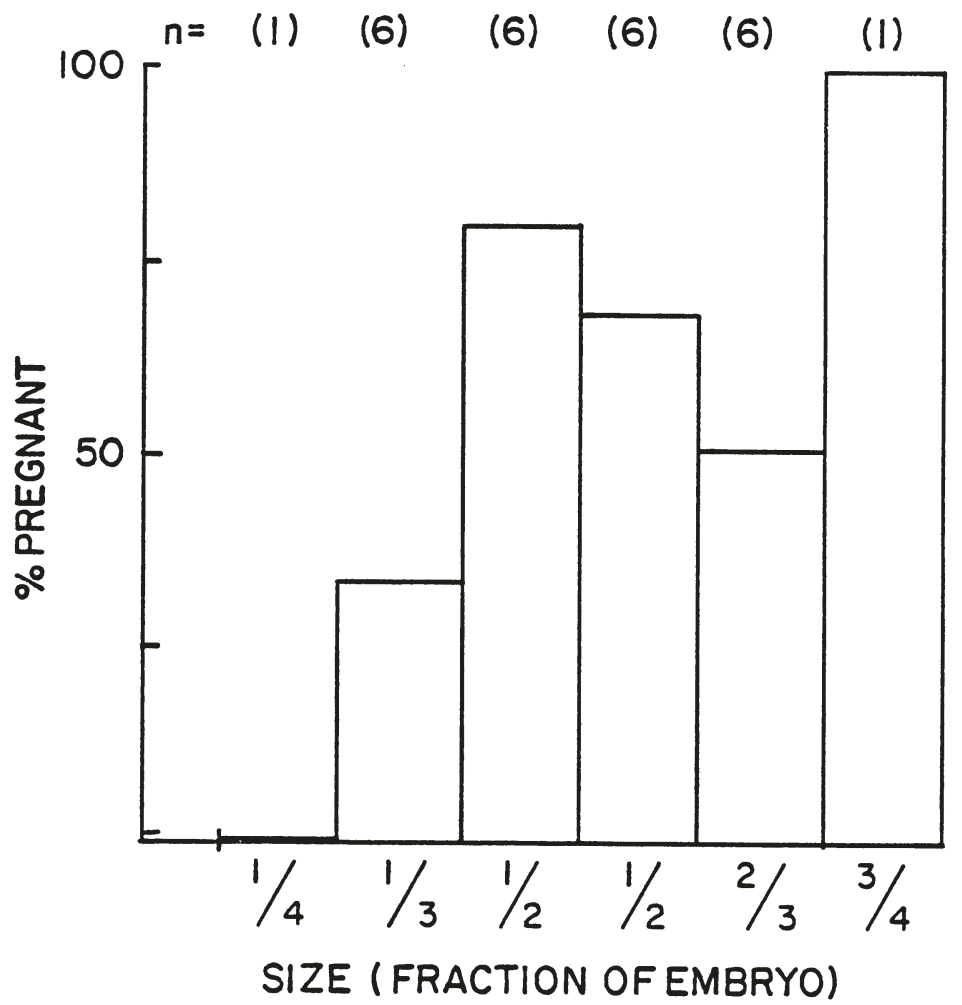

Fig u re 6. Effect of size of half-embryos on the pregnancy rates following non-surgical transfers. 
remaining 10 recipients gave birth to normal calves. The 5 pairs of monozygotic half-embryos transferred in pairs resulted in one pair of males and two pairs of females (of which one pair was stillborn), for a twinning rate of $60 \%$ with no single births.

The relationship between the size of the half-embryo and the pregnancy rate for the single transfers is represented in Fig. 6. There was no significant difference between the 6 groups.

\section{DISCUSSION}

The results of the in vitro experiment clearly show that there is often a difference in viability between the two "halves" of the same embryo. This effect increases with the size difference of the "halves" and also with the time in culture. A rapid decrease in the viability of half-embryos in culture up to $24 \mathrm{~h}$ has been previously reported (Picard et al. 1984, Baker \& Shea 1985). This experiment has shown that most losses of viability can be attributed to failure of the smaller "halves" $(1 / 4,1 / 3)$. However, the results also demonstrated a marked difference in viability in vitro even within pairs of half embryos that were initially about the same size $(1 / 2,1 / 2)$. Unfortunately, in the 18 to $24 \mathrm{~h}$ group, it was not possible to make a direct link between the morphology immediately after division and after culture since the former observations were not recorded. Separation of pairs by size or morphology showed the "good" halves to have a higher cell content and better cytological characteristics after $24 \mathrm{~h}$ culture. Regrouping half-embryos into viable $(A \& B)$ and nonviable $(C \& D)$ classes showed that the viable halves had a higher cell content irrespective of their classification as "good" or "poor". This was also recorded in a previous study (Picard et al. 1985) where it was shown that within the "poor" halves after $4 \mathrm{~h}$ of culture, viability was positively related to cell numbers. However, there is evidence that the number of cells itself is not necessarily the critical factor in the degeneration of these embryos because, when they are divided before compaction, a very high proportion of quarter embryos develop normally after culture in the sheep oviduct, despite containing only one quarter of the normal cell content (Willadsen et al. 1981, Willadsen \& Polge 1981, Willadsen 1982). Rather, the degenerate appearance seems to be related to poor recompaction of the halves. One factor that could be involved in the association of rapid degeneration with low cell numbers is an inadequate in vitro culture 
system: because culture media are generally unsuitable for sustaining embryos for an extended period of time (Hahn et al. 1978, Renard et al. 1980, Kuzan \& Wright 1982), progressive loss of cells would obviously lead to first signs of overall degeneration in vitro in the smaller half-embryos. Another factor is undoubtedly the cell wastage induced during the bisection process: destruction of some cells by the cutting blade was visible (Fig. 2) and was also evidenced by a lower (though not significantly so) cell number of the sum of the two halves compared with the unsplit controls (Table 2). Electron microscopy of half embryos has also shown degenerating cells along the cut surface (J $\phi r$ gensen et al. 1985). Overall, these observations suggest that the degenerate appearance is associated with a high proportion of pyknotic cells and a low cell number and, conversely, that the viability of half-embryos depends upon their initial size and the extent of the damage they incurred during their formation.

No clear difference of viability between the "good" and "poor" halves of the same embryo could be demonstrated by the in vivo transfer experiment, possibly because numbers were small (Fig. 6). Demonstration of any statistical significance in survival rates will require large numbers of transfers because so many other factors can affect results; 30 to $40 \%$ of even very good quality whole embryos do not survive after transfer. However, Baker et al. (1984) have reported an important decrease in the pregnancy rate obtained with smaller half-embryos (those comprising only 30 to $40 \%$ of the original mass). Willadsen et al. (1981) reported a difference of $34 \%$ in the pregnancy rate given by transfer of very good quality half- and quarter-embryos split before compaction, indicating that embryos with fewer cells at a given developmental stage have less chance of maintaining the pregnancy. It can therefore be expected that this difference will be seen, and perhaps exaggerated, following division of post-compaction embryos in which some of the cells aer destroyed. Combining the data available for pre- and postcompaction embryos, it is difficult to know whether the lower pregnancy rate obtained with the smaller halves is due to a real reduction in embryo viability (in vivo culture of post-compaction halves has not been studied) or just to a diminished capacity to convey embryonic signals to the recipient to prevent her return to oestrus.

The general results of the transfers (pregnancy and twinning 
rates) in this experiment are similar to those reported by others (Ozil et al. 1982, Lambeth et al. 1983, Ozil 1983, Williams et al. 1984, Picard et al. 1985) although the 5 monozygotic pairs transferred produced a relatively high $(60 \%)$ twinning rate. With post-compaction splitting, the twinning rates are generally under $50 \%$. In many cases only one half survives even when both halves are transferred to the same recipient (Ozil et al. 1982, Lambeth et al. 1983, Ozil 1983, Picard et al. 1985). The general observation that there is no tendency for both halves to survive or die further suggests the existence of a difference in viability between the two halves. In contrast, following division before compaction, the twinning rate at 50 days can be very high (71\%) (Willadsen et al. 1981).

In this study only good and excellent quality embryos were used for micromanipulation. Embryos presenting signs of degeneration should be rejected for splitting because they contain fewer viable cells (Linares 1981) or show poor compaction. The ideal post-compaction stage for splitting was reported to be the blastocyst or early blastocyst (Williams et al. 1984), probably because of the higher cell numbers and tight compaction in the embryos at these stages. In practical terms, good results depend on careful technique that produces uniform halves with minimal cell damage. Then, because long-term culture of half-embryos is detrimental to survival in vivo (Baker \& Shea 1985) as well as in vitro, they should be transferred as soon as possible after splitting.

There is no doubt that embryo bisection can be used to increase the pregnancy rate per embryo in commercial embryo transfer units and to produce genetically identical twins which are invaluable for many experiments. However, it is evident that one half-embryo cannot be used as a control for the other half in viability experiments when they are split after compaction. A better alternative would seem to be to form the half-embryos by division before compaction (when the cells can be counted) and then to reevaluate them for their similarity after culture in sheep or rabbit oviducts before use.

\section{ACKNOWLEDGEMENTS}

This work was supported by the Conseil de Recherche et Services Agricoles du Québec (CRSAQ) and Natural Sciences and Engineering Research Council (NSERC). The authors also wish to thank Dr. P. Guay for professional collaboration; R. Bériault and G. Pineault for skilled technical assistance and S. Lagacé for typing the manuscript. 


\section{REFERENCES}

Baker, R. D., B. K. Eberhard, R. E. Leffel, R. F. Rohde \& T. J. Henschen: Pregnancy rates following surgical transfer of bovine demi-embryos. Proc. 10th Int. Congr. An. Reprod. A.I., UrbanaChampaign, Illinois 1984, p. 220.

Baker, R. D. \& B. E. Shea: Commercial splitting of bovine embryos. Theriogenology 1985, 23, 3-12.

Bronson, R. A. \& A. McLaren: Transfer to the mouse oviduct of eggs with and without the zona pellucida. J. Reprod. Fert. 1970, 22, $129-137$.

Ducibella, T., D. F. Albertini, E. Anderson \& J. D. Biggers: The preimplantation mammalian embryo: Characterization of intercellular junctions and their appearance during development. Develop. Biol. 1975, 45, 231-250.

Elsden, R. P., L. D. Nelson \& G. E. Seidel Jr.: Superovulating cows with follicle stimulating hormone and pregnant mare's serum gonadotropin. Theriogenology 1978, 9, 17-26.

Gardner, R. L.: An investigation of inner cell mass and trophoblast tissues following their isolation from the mouse blastocyst. J. Embryol. exp. Morph. 1972, 28, 279-312.

Greve, T.: Bovine egg transplantation in Denmark. Ph.D. Thesis, The Royal Veterinary and Agricultural University, Copenhagen, Denmark 1981.

Hahn, J., L. A. Moustafa, V. Schneider, R. Hahn, W. Romanowski \& $R$. Roselius: Survival of cultured and transported bovine embryos following surgical and non-surgical transfer. In: Control of Reproduction in the Cow, ed. J. M. Sreenan. Martinus Nijhoff, The Hague 1978, 356-361.

Hogan, B. \& R. Tilly: In vitro development of inner cell masses isolated immunosurgically from mouse blastocysts. J. Embryol. exp. Morph. 1978, 45, 107-121.

Johnson, M. H. \& C. A. Ziomek: Cell subpopulations in the late morula and early blastocyst of the mouse. Develop. Biol. 1982, 91, 431 $-439$.

Jørgensen, P. H., P. Hyttel \& L. Picard: Transmission and scanning electron microscopy of bisected bovine compact morulas and early blastocysts. Proc. Soc. Study Fertil. Aberdeen 1985, abstract 13.

King, W. A.: Sexing embryos by cytological methods. Theriogenology 1984, 21, 7-17.

Kuzan, F. B. \& R. W. Wright Jr.: Observations on the development of bovine morula on various cellular and non-cellular substrata. J. Anim. Sci. 1982, 54, 811-816.

Lambeth, V. A., C. R. Looney, S. A. Voelkel, D. A. Jackson, K. G. Hill, $\& R$. A. Godke: Microsurgery on bovine embryos at the morula stage to produce monozygotic twin calves. Theriogenology 1983 , $20,85-95$.

Linares, T.: Embryonic development in repeat breeder and virgin heifers seven days after insemination. Ph.D. Thesis, Swedish University of Agricultural Sciences. Uppsala, Sweden 1981. 
Massey, J. M., J. G. Anderson, W. C. Ellis, A. M. Sorensen Jr. \& D. C. Kraemer: Development of bovine embryas following enzymatic removal of the zona pellucida. Theriogenology 1982, 17, 99 (abstract).

Modlinski, J. A.: The role of the zona pellucida in the development of mouse eggs in vivo. J. Embryol. exp. Morph. 1970, 23, 539-547.

Ozil, J. P.: Production of identical twins by bisection of blastocysts in the cow. J. Reprod. Fert. 1983, 69, 463-468.

Ozil, J. P., Y. Heyman \& J. P. Renard: Production of identical twins by micromanipulation and cervical transfer in the cow. Vet. Rec. 1982, 110, 126-127.

Picard, L., W. A. King \& K. J. Betteridge: Cytological studies of bovine half-embryos. Theriogenology 1984, 21, 252 (abstract).

Picard, L., W. A. King \& K. J. Betteridge: Production of sexed calves from frozen thawed embryos. Vet. Rec. 1985, 117, 603-608.

Pratt, H. P. M., C. A. Ziomek, W. J. D. Reeve \& M. H. Johnson: Compaction of the mouse embryo: an analysis of its components. J. Embryol. exp. Morph. 1982, 70, 113-132.

Renard, J. P., Y. Heyman \& J. P. Ozil: Importance of gestation losses after non-surgical transfer of cultured and non-cultured bovine blastocysts. Vet. Rec. 1980, 107, 152-153.

Tarkowski, A. K. \& J. Wroblewska: Development of blastomeres of mouse eggs isolated at the 4 and 8 cell stage. J. Embryol. exp. Morph. 1967, 18, 155-180.

Trounson, A. O. \& N. W. Moore: The survival and development of sheep eggs following complete or partial removal of the zona pellucida. J. Reprod. Fert. 1974, 41, 97-105.

Voekel, S. A., S. D. Viker, C. A. Johnson, K. G. Hill, P. E. Humes \& R. A. Godke: First calves produced from quartered embryos. Louisiana Agric. 1984, 27, 5.

Wiley, L. M., A. I. Spindle \& R. A. Pedersen: Morphology of isolated mouse inner cell masses developing in vitro. Develop. Biol. 1978, $63,1-10$.

Willadsen, S. M.: A method for culture of micromanipulated sheep embryos and its use to produce monozygotic twins. Nature (Lond.) 1979, 277, 298-300.

Willadsen, S. M.: Micromanipulation of embryos of the large domestic species. In: Mammalian Egg Transfer, ed. C. E. Adams, GRC Press Inc., Boca Raton, Florida 1982, p. 185-210.

Willadsen, S. M. \& C. B. Fehilly: The developmental potential and regulatory capacity of blastomeres from two, four and eight cell sheep embryos. In: Fertilisation of the human egg in vitro, eds. H. M. Beier and H. R. Linder, Springer-Verlag, Berlin, Heidelberg, New York, Tokyo 1983, p. 353-357.

Willadsen, S. M., H. Lehn-Jensen, C. B. Fehilly \& R. Newcomb: The production of monozygotic twins of preselected parentage by micromanipulation of non-surgically collected cow embryos. Theriogenology $1981,15,23-29$. 
Willadsen, S. M. \& C. Polge: Attempts to produce monozygotic quadruplets in cattle by blastomere separation. Vet. Rec. 1981, 108, 211-213.

Williams, T. J., R. P. Elsden \& G. E. Seidel Jr.: Bisecting bovine embryos: Methods, application and success rates. Ann. Conf. on Art. Ins. and Embr. Trans. in Beef Cattle, Denver, Colorado 1983, p. 45-51.

Williams, T. J., R. P. Elsden \& G. E. Seidel Jr.: Pregnancy rates with bisected bovine embryos. Theriogenology 1984, 22, 521-531.

Williams, T. J. \& G. E. Seidel Jr.: Methodology and equipment for microsurgery with mammalian ova. Proc. Worksh. IXth Ann. Meet. Internat. Embryo Transfer Soc., Fort Collins, Colorado 1983, p. $33-52$.

Ziomek, C. A., M. H. Johnson \& A. H. Handyside: The developmental potential of mouse 16-cell blastomeres. J. exp. Zool. 1982, 221, $345-355$.

\section{SAMMENDRAG}

Mikrokirurgisk deling af sene morula- eller blastocyststadier:

Forskelle $i$ overlevelsesevne mellem de to monozygotiske halvdele.

Mikrokirurgisk deling af bovine morula- eller blastocyststadier er blevet en integreret del af embryotransplantationsarbejdet og kan i mange tilfælde forbedre resultaterne meget væsentligt. Bisektion af morula-blastocyststadier er simplere end deling af de prækompakte stadier, men vil altid medføre nogen cellulær beskadigelse. Desuden er det praktisk umuligt at frembringe to fuldstændig identiske halvdele. Monozygotiske halvdele kan derfor altid opdeles i en "god“ og en „dårlig“ halvdel. Det var dette studiums primære sigte at undersøge viabiliteten af de "gode“ og „dårlige“ halvdele.

Efter 4-6 timers dyrkning in vitro var de "gode" halvdele mere levedygtige end en „,dårlig“. En cytologisk vurdering efter 24 timers dyrkning in vitro afslørede, at den morfologisk bedst udseende halvdel indeholdt flere celler end dens tilsvarende tvilling (gns. 45,9 celler mod 23,0 celler). Desuden havde den gode halvdel et højere mitotisk indeks end den dårlige $(6,1 \% \bmod 3,1 \%)$.

Ikke-kirurgisk transplantation af 26 halve embryoner til 26 synkroniserede recipienter resulterede i 15 drægtigheder $(55,6 \%)$. Det var dog ikke muligt at demonstrere en forskel i drægtighedsprocenten mellem gode og dårlige eller store og små halvdele.

In vitro resultaterne underst $\varnothing$ ttede imidlertid teorien om, at større halvdele har bedre overlevelseschancer end små halvdele.

In vivo resultaterne af total overlevelse viste, at den ene halvdel ikke kan anvendes som kontrol for dens monozygotiske tvilling efter transplantation.

(Received November 6, 1985).

Reprints may be requested from: L. Picard, C.R.R.A., Faculté de Médecine Vétérinaire, Université de Montréal, C.P. 5000, St.-Hyacinthe, Québec, Canada J2S 7C6. 